\title{
Hukum Sumber Daya Genetik, Pengetahuan Tradisional DAN EKspresi BUdaya Tradisional di Indonesia
}

\author{
Isna Fatimah
}

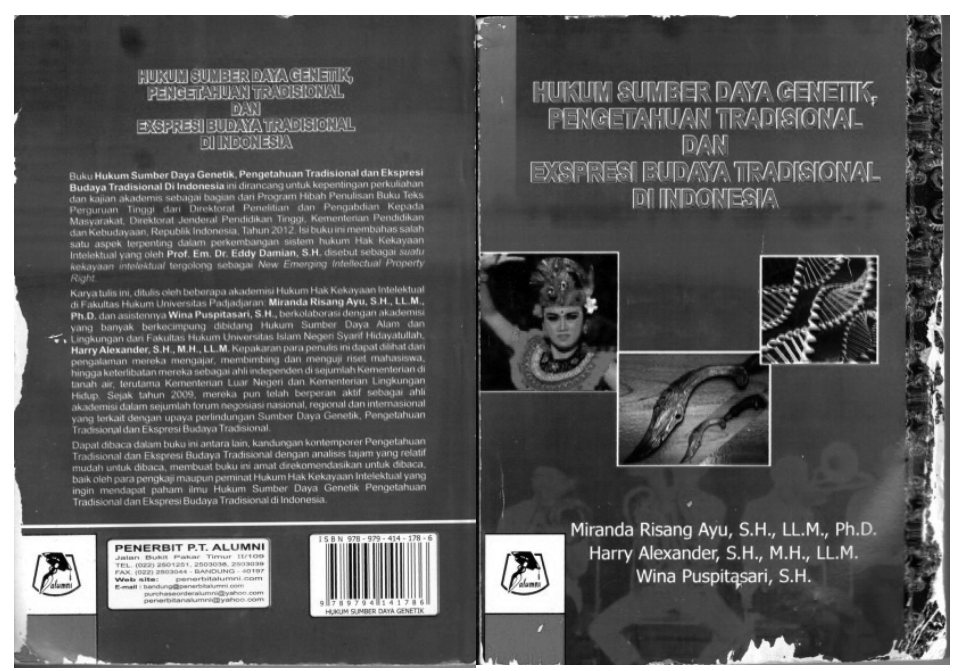

Penulis

: Miranda Risang Ayu, S.H., LL.M, Ph.D

Harry Alexander, S.H., M.H., LL.M.

Wina Puspitasari, S.H.

Judul Buku : : Hukum Sumber Daya Genetik, Pengetahuan

Tradisional dan Ekspresi Budaya Tradisional di Indonesia

Penerbit

: PT. Alumni

Kota terbit

: Bandung

Waktu terbit

: Cetakan ke-1 tahun 2014

Jumlah halaman

: 459 halaman (termasuk 16 halaman dengan huruf romawi)

ISBN

: 978-979-414-178-6

Telaah tentang mekanisme pelindungan sumber daya genetik menjadi tuntutan yang sifatnya cukup mendesak bagi Indonesia. Sebagai negara yang 
mendapat julukan mega-diversity country, sumber daya genetik dari biota endemik di Indonesia menjadi sasaran penelitian dan pengembangan baik untuk kepentingan ilmu pengetahuan maupun pemanfaatan. Tidak jarang Indonesia menjadi korban pemanfaatan sumber daya genetik yang tidak bertanggung jawab seperti biopiracy. Pelindungan sumber daya genetik di Indonesia sendiri memiliki keunikan karena terdapat beberapa jenisnya yang secara tradisional dan turun-temurun sudah dimanfaatkan oleh masyarakat Indonesia. Selain itu, Indonesia juga kental dengan keragaman Ekspresi Budaya Tradisional yang sangat dekat atau terinspirasi dengan alamnya, sehingga memiliki keterkaitan juga dengan nilai dari sumber daya genetik. Indonesia juga menjadi anggota dari berbagai komitmen internasional berkenaan dengan Sumber Daya Genetik yang secara otomatis juga mengaitkan isu Pengetahuan Tradisional dan Ekspresi Budaya Tradisional diantaranya Convention on Biological Diversity dan UNESCO Convention for the Safeguarding of the Intangible Cultural Heritage of Mankind 2003.

Tujuan dari penulisan buku "Hukum Sumber Daya Genetik, Pengetahuan Tradisional dan Ekspresi Budaya Tradisional di Indonesia" pada dasarnya adalah memberikan penjelasan tentang kerangka hukum sumber daya genetik, pengetahuan tradisional dan ekspresi budaya tradisional yang telah ada di Indonesia. Tidak berhenti di situ, dengan menggali lebih dalam makna dan tujuan mendasar dari berbagai jenis hukum yang hidup di Indonesia, hukum internasional, serta membandingkan dengan pelaksanaan di negara lain terkait bidang Sumber Daya Genetik, Pengetahuan Tradisional dan Ekspresi Budaya Tradisional (SDGPTEBT), buku ini memberikan beberapa rekomendasi kebijakan dan pengaturan dalam bingkai pemenuhan hak ekonomi masyarakat, hak-hak komunal dan hak budaya yang dikontekstualisasikan sebagai bagian dari hak asasi manusia.

Sebagai karya ilmiah di bidang hukum, buku ini memberikan perspektif mengenai penilaian atas norma yang sudah berlaku dengan kebutuhan pelindungan hak-hak masyarakat yang mempunyai pengetahuan tradisional atau ekspresi budaya tradisional atas sumber daya genetik. Dengan demikian, pendekatan penelitian dilakukan melalui analisis bahan hukum primer, dalam hal ini terbatas pada hukum positif yang berlaku terkait dengan SDGPTEBT, hak asasi manusia (terutama hak masyarakat adat), hak kekayaan intelektual, dan penguasaan sumber daya alam. Selain itu buku ini juga merujuk pada bahan hukum sekunder termasuk Rancangan Undang-Undang (RUU) tentang Pelestarian dan Pemanfaatan Sumber Daya Genetik, RUU tentang Perlindungan dan Pemanfaatan Kekayaan Intelektual 
Pengetahuan Tradisional dan Ekspresi Budaya Tradisional, dan RUU tentang tentang Konservasi Keanekaragaman Hayati.

Buku ini disusun oleh tiga penulis yang masing-masing berpengalaman dalam menggeluti isu terkait perlindungan hukum sumber daya genetik dan pengetahuan tradisional di kancah akademis maupun praktis. Masing-masing penulis berpengalaman dalam mendalami isu tersebut dengan pendekatan yang berbeda namun saling melengkapi. Penulis pertama mempunyai spesialisasi utama di bidang hukum kekayaan intelektual, penulis kedua mempunyai spesialisasi utama di bidang hukum energi dan sumber daya alam sementara penulis ketiga spesialisasi utamanya pada hukum adminsitrasi negara.

Adapun anatomi substantif buku ini terdiri dari sepuluh Bab yaitu:

1. Pendahuluan

2. Pengertian dan Ruang Lingkup Sumber Daya Genetik, Pengetahuan Tradisional dan Ekspresi Budaya Tradisional

3. Ketentuan Hukum Terkait Sumber Daya Genetik, Pengetahuan Tradisional dan Ekspresi Budaya Tradisional

4. Jenis-Jenis Perlindungan Sumber Daya Genetik, Pengetahuan Tradisional dan Ekspresi Budaya Tradisional

5. Kepemilikan dan Penerima Manfaat

6. Pemanfaatan Sumber Daya Genetik, Pengetahuan Tradisional, dan Ekspresi Budaya Tradisional

7. Akses dan Pembagian Keuntungan

8. Kelembagaan

9. Strategi Perlindungan Pengetahuan Tradisional di Peru, Afrika Selatan dan India

10. Studi Kasus

Kemudian di bagian lampiran dimuat tabel perbandingan pengaturan tentang pelestarian dan pemanfaatan sumber daya alam hayati yang sudah ada di Indonesia berdasarkan Nagoya Protocol on Access to Genetic Resources and the Fair and Equitable Sharing of Benefits Arising from Their Utilization to the Convention on Biological Diversity (Protokol Nagoya). 
Pada awal penjelasan, dipaparkan tentang pengertian dari SDGPTEBT berdasarkan gagasan ahli yang relevan baik dari kalangan akademisi maupun negosiator di tingkat internasional. Selanjutnya dipaparkan berbagai peraturan perundang-undangan Indonesia yang pengaturannya memiliki keterkaitan dengan SDGPTEBT. Meskipun belum banyak pengaturan yang spesifik tentang SDGPTEBT, namun banyak dari peraturan perundang-undangan yang dipilih telah mengatur tentang hak masyarakat adat atas sumber daya alam ataupun pengetahuan tradisional. Keberpihakan bagi pemenuhan hak-hak masyarakat adat atas pemanfaatan SDGPTEBT terlihat dalam buku ini. Namun demikian, di antara semua peraturan perundang-undangan yang dianggap memiliki keterkaitan dengan SDGPTEBT, buku ini belum membahas Undang-Undang No. 16 Tahun 2014 tentang Desa (UU Desa) yang dianggap memberikan warna baru dalam konstelasi peraturan yang bermaksud melindungi hak-hak masyarakat secara umum. Hal ini dapat dimaklumi karena pengundangan UU Desa dilakukan pada tahun yang sama dengan tahun terbit buku ini. Pada bagian ketentuan hukum ini juga dipetakan instrumen hukum internasional yang mempengaruhi pengelolaan SDGPTEBT yang dikelompokkan dalam 3 (tiga) bagian yaitu: hukum hak asasi manusia, hukum hak kekayaan intelektual, dan hukum sumber daya alam dan lingkungan.

Buku ini memberikan gambaran tentang pilihan jenis-jenis perlindungan SDGPTEBT yang bisa menjadi rekomendasi bagi langkah awal pengambilan kebijakan oleh pemerintah. Adapun rekomendasi yang diberikan hanya sampai pada penjabaran hasil diskursus akademis, tidak bermaksud melakukan persuasi. Selain itu, rekomendasi juga tidak sampai pada hal-hal yang bersifat terlalu teknis karena masing-masing jenis perlindungan disajikan pada tatanan deskriptif-objektif.

Komposisi pembahasan tentang pengetahuan tradisional, hak kebudayaan dan hak-hak komunal masyarakat adat terlihat paling menonjol dalam buku ini dibandingkan tentang sumber daya genetiknya sendiri. Hal ini dikarenakan perspektif yang dipilih penulis adalah bagaimana pemanfaatan sumber daya genetik mendatangkan keuntungan bagi masyarakat adat atau lokal di Indonesia yang mempunyai hak berdasarkan mekanisme ABS. Buku ini telah mencoba menganyam titik temu antara sistem hukum Hak Kekayaan Intelektual dengan pengetahuan tradisional dan/atau hak kebudayaan. Adapun dalam Bab mengenai ABS, penulis memberikan beberapa ide tentang indikator yang harus dipenuhi dalam menyusun peraturan nasional tentang ABS di Indonesia. Satu ide yang paling menonjol adalah pemisahan antara izin akses dan izin pemanfaatan sumber daya genetik serta perjanjian pemanfaatan sebagai syarat pengajuan perjanjian pemanfaatan. 
“Perjanjian pemanfaatan dilakukan dalam rangka permohonan izin pemanfaatan terhadap Pengetahuan Tradisional. Untuk melakukan penyusunan perjanjian pemanfaatan, pihak pengguna terlebih dahulu telah memiliki izin akses. Untuk menindaklanjuti informasi yang diperoleh dari kegiatan akses tersebut ke dalam suatu kegiatan pemanfaatan, pihak pengguna harus memiliki izin pemanfaatan. Dalam permohonan izin pemanfaatan, disyaratkan adanya perjanjian pemanfaatan yang dilakukan oleh pihak pengguna dengan komunitas sumber dengan bantuan lembaga pemerintah terkait. Perjanjian pemanfaatan merupakan dokumen yang harus disertakan dalam permohonan izin pemanfaatan..." (hlm. 226).

Penjelasan selanjutnya dalam buku ini lebih dititikberatkan pada perlindungan yang berkaitan dengan hak-hak ekonomi dari pemanfaatan SDGPTEBT bagi masyarakat adat atau lokal. Sebagian besar substansinya berbicara tentang pembagian keuntungan sebagai umpan balik dari perlindungan pengetahuan tradisional dan hak-hak komunal di bidang hak kekayaan intelektual. Unsur pelindungan SDG sebagai komponen lingkungan hidup tidak banyak dibahas. Dapat dikatakan pendekatan yang dipilih penulis lebih bersifat antroposentris. Buku ini memosisikan Indonesia sebagai si terwajib dalam pelaksanaan komitmen internasional bidang akses dan pembagian keuntungan karena komitmen tersebut pada akhirnya akan mendatangkan keuntungan, melalui mekanisme Akses dan Pembagian Keuntungan (Access and Benefit Sharing/ABS). Hal ini terlihat dalam penjelasan tentang kepemilikan dan penerima manfaat dari pemanfaatan SDGTPEBT serta akses dan pembagian keuntungan. Akibatnya, buku ini belum merangsang kepekaan pembaca akan urgensi pelestarian sumber daya genetik di Indonesia yang hingga saat ini sudah mengalami degradasi hebat hingga berkontribusi pada perusakan lingkungan hidup.

Secara garis besar, buku ini sangat bermanfaat untuk mendapatkan pemahaman tentang hukum yang berkaitan dengan SDGPTEBT, meskipun tidak sampai pada pelindungan SDG sebagai komponen pendukung integritas lingkungan hidup. Sampai saat ini buku "Hukum Sumber Daya Genetik, Pengetahuan Tradisional dan Ekspresi Budaya Tradisional di Indonesia" menjadi satu-satunya buku berbahasa Indonesia yang secara spesifik mengangkat isu sumber daya genetik dan membandingkannya dengan regulasi dan kebijakan yang sudah berlaku di Indonesia. Meskipun tentunya untuk mendapat pemahaman komprehensif tentang isu SDGTKEBT tidak bisa tanpa membaca literatur lain terutama yang disusun oleh 
ISNA FATIMAH

United Nations, Food and Agriculture Organization, dan World Intellectual Property Organization. 